GEOGRAFICKÝ ČASOPIS / GEOGRAPHICAL JOURNAL 72 (2020) 4, 337-349

DOI: https://doi.org/10.31577/geogrcas.2020.72.4.17

\title{
ESENCIALISTICKÝ (TRADIČNÝ) VERZUS KONŠTRUKTIVISTICKÝ PRISTUP K REGIONÁLNEJ IDENTITE
}

\author{
Karol Kasala* \\ * Univerzita Komenského v Bratislave, Prírodovedecká fakulta, Katedra regionálnej geografie, ochrany \\ a plánovania krajiny, Mlynská dolina, Ilkovičova 6, 84215 Bratislava, Slovensko, karol.kasala@uniba.sk
}

\begin{abstract}
Essentialist (traditional) versus constructivist approach to regional identity
Identity is a concept with growing importance in the humanities, several social sciences as well as in geography. This article introduces the "traditional" concept of identity as it was understood in the past as well as (less frequently) today. A brief overview of changes of the understanding of the concept of identity in the social sciences is presented. The consequences of the development of the identity concept on the changes in the geographical understanding of identity are assessed and discussed.
\end{abstract}

Key words: identity, regional identity, social construction, identity politics

\section{ÚVOD A CIELE PRÍSPEVKU}

Identita je v súčasnosti často používaným až nadužívaným pojmom, predovšetkým v sociálnych a humanitných vedách. V geografii si získava rastúcu pozornost' regionálna identita. Pod týmto pojmom budeme rozumiet' geografický koncept identity.

Koncepcia identity v historickom vývoji odrážala dlhodobo jej chápanie, ako sa utváralo vo filozofii - teda v zmysle totožnosti (Bricker 2006 a Lazor 2010). Individuálna identita osoby, veci, regiónu odrážala jej individuálne charakteristické črty, špecifické odlišnosti. Individuálna identita - identita jednotlivca sa v psychológii zameriava na seba, v zmysle totožnosti a jej vedomia (Petrusek 1996), konfrontácie seba s vonkajším svetom (Erikson 1977) a interakcie druhými (Roubal 2009). A podobne boli formy skupinovej identity (kolektívna, etnická, religiózna, sociálna a pod.) vymedzované na základe skupinovej identifikácie, vymedzovania my - oni, akcentujúc špecifiká a odlišnosti. Sociologické chápanie identity zdôrazňuje predovšetkým sociálnu identitu (Jenkins 2008); sám sebou sa stávam prostredníctvom druhých (Bauman a May 2004).

Chápanie identity sa výrazne zmenilo od polovice 20. storočia. Sociálny konštruktivizmus (Berger a Luckmann 1999), politika identity (Keith a Pile 1993) a postštrukturalistická subjektivizácia prispeli postupne $\mathrm{k}$ meniacemu sa chápaniu identity, pričom je dôležité zdôraznit' rastúci význam aktérov tejto zmeny. K hlbokej zmene $z$ esencialistického chápania na sociálnokonštruktivistické chápanie nestálej a hybridnej identity prispeli sociálne revolúcie 60 . rokov 20 . storočia, teoretici feminizmu, postštrukturalizmu a postkolonializmu a politika identity. V príspevku si všímame najprv identitu ako „tradičný“ (esencialistický) koncept vo filozofii a sociálnych vedách, d’alej esencialistické poňatie regionálnej identity a chápanie identity po ,postmoderno-postštrukturalistickom obrate“ najprv v sociálnych vedách a potom $v$ geografii.

Hlavným ciel'om príspevku je objasnit' súvis medzi súčasným chápaním konceptu identity v geografii (regionálnej identity) a zmenami chápania identity 
v sociálnej teórii v období od 80 . rokov 20. storočia. Čiastkové ciele predkladanej štúdie boli: uviest' ,tradičný koncept identity“, ako bola chápaná v minulosti a čiastočne aj $\mathrm{v}$ súčasnosti; predložit' krátky prehl'ad zmien chápania konceptu identity v sociálnych vedách; stručne poukázat' na dôsledky vývoja konceptu identity ako sociálnej kategórie na regionálnu identitu a diskutovat' o vzt’ahu tradičného versus sociálnokonštruktivistického chápania regionálnej identity. Dôraz na diskusný charakter príspevku predurčuje $\mathrm{z}$ metodického hl'adiska predovšetkým rešerš relevantnej literatúry, jednak z oblasti identity v geografii, ako aj v sociálnych vedách. Diskusia má komparatívny charakter, zdôrazňuje príklon autora $\mathrm{k}$ tradične chápanej regionálnej identite a prakticky sa sústred'uje najmä na stručný prehl'ad nedostatkov sociálnokonštruktivistického ponímania identity $\mathrm{v}$ geografii a $\mathrm{v}$ sociálnych vedách a na vyvrátenie námietok proti tradične chápanej regionálnej identite.

$\mathrm{V}$ tomto príspevku budeme pre zjednodušenie používat' všeobecný pojem regionálna (geografická) identita, ktorým chápeme regionálnu identitu v užšom zmysle - lokálnu, národnú i nadnárodnú identitu, ako aj príbuzné koncepty (sense of place, genius loci a pod.) a zároveň identitu regiónu, ako aj regionálnu identitu (Paasi 1986). Podobne budeme používat’ pojem ,sociálny konštruktivizmus“, ktorý je v našom vedeckom prostredí viac používaný než „sociálny konštrukcionizmus“.

\section{IDENTITA V GEOGRAFII DO 80. ROKOV 20. STOROČIA}

Identita sa v geografii v období do 50 . rokov 20. storočia formovala v prostredí prevládajúcej regionálnogeografickej paradigmy. Práce, ktoré by sme mohli označit' ako zamerané na „tradičnú identitu“, však pojem identita nepoužívajú. V tejto časti príspevku sa sústredíme na dva prístupy k regionálnej identite: koncept kultúrneho (vernakulárneho a percepčného) regiónu/krajiny a humanistickogeografickú predstavu významu miesta (sense of place). Pod pojmom kultúrny región budeme zjednodušene rozumiet' niekol'ko tradícií v americkej geografii: kultúrnu krajinu v zmysle Sauera (1925), resp. sauerovskej školy kultúrnej geografie, sčasti z nej vychádzajúce novšie prístupy, spomenieme najmä Jacksona a Meiniga; koncept vernakulárneho regiónu (Zelinsky a Jordan) a percepčný región. Prekrytie medzi krajinárskou tradíciou (landscape tradition) a humanistickogeografickým prístupom $\mathrm{k}$ identite (sense of place) je vel'mi silné, jednotlivých autorov a smery možno tak t’ažko jednoznačne zaradit'. Regionálnej identite sú príbuzné aj d’alšie koncepty: genius loci (Norberg-Schulz 1994), značka regiónu (Matlovičová 2015) a pod.

„Žiadne dve miesta na Zemi nie sú identické“ (James 1954, p. 8). Identita teda súvisí s osobitost'ou, špecifičnost'ou regiónov, a tak aj bola až do nástupu humanistickej geografie chápaná. Francúzska regionálnogeografická škola prvej polovice 20. storočia popisuje pays, predovšetkým rurálno-pol’nohospodárske regióny, ktoré sú späté s pocitom prináležitosti (Claval 2007). Sú to holistické štúdie, zdôrazňujúce zakorenenost' a personalitu (Annette 1965). Podobne sa personalite regiónu venovali práce $\mathrm{z}$ iných národných škôl. Príkladom je práca o personalite Írska (Estyn Evans 1973), v nadväznosti na francúzsku školu stavajúcu na kultúre a historickom odkaze. V americkej geografii sa na medzivojnovej tradícii kultúrnej krajiny (Sauer 1925) a etáp osídl'ovania (sequent occupance; Whittlesey 1929) rozvinul špecifický prístup kultúrnych geografov zdôrazňujúci historicitu, špecifiká a identitu (Meinig 1969, Jackson 1972 a Zelinsky 1973).

Regionálnej identite je blízky koncept percepčného a vernakulárneho regiónu. Kým percepčné regióny sú regiónmi v mysli, skúmanými behaviorálnou geografi- 
ou, vernakulárne regióny sú skôr kultúrnogeografickými regiónmi (Marek 2020a). Percepčné regióny ako súčast' behaviorálnogeografického výskumu sa zameriavali o. i. na mentálne mapy (napr. Gould a White 1986 vychádzajú z obrazu miest a predkladajú množstvo príkladov priestorovej percepcie a mentálnych máp z celého sveta). Jordan (1978) vyčlenil na základe 3800 dotazníkov, uskutočnených študentami a učitel'mi univerzít a stredných škôl, 29 percepčných regiónov Texasu. Respondenti boli inštruovaní, že majú vybrat' svoju „domovskú oblast”“ (home country), ktorou nemusí byt' ich rodisko. Vernakulárnymi regiónmi sú napr. Nové Anglicko, Stredozápad, Biblický pás (Bible Belt), Dixieland, Akádia a pod. (vid’ aj Zelinsky 1980). Toto smerovanie je späté s výrazným nárastom prác zameraných na regionálnu identitu v pravom slova zmysle.

Práce v americkej geografii vychádzajú z tradície doznievajúcej regionálnogeografickej paradigmy, ktorá zdôrazňovala špecifiká regiónu a unikátnost' miesta (Parsons 1955). Jackson (1972) tak hodnotí priestorový vývoj v USA v dekáde po občianskej vojne v USA ako v celku a potom v jeho regiónoch. Špecifiká zdôrazn̆ujú názvy podkapitol, v prvej časti sú to: Po vojne; Expanzia; Prostredia a Reformátori.

Jackson (1994) zdôrazňuje úlohu symbolov (automobil a iné) v identite Ameriky a popisuje, ako menili charakter krajiny a vzt'ah $\mathrm{k}$ nej (awarenes of the landscape). Dáva odpoved' na to, kto sme a kam patríme. „Byt' čast’ou krajiny, odvodit' $\mathrm{z}$ nej našu identitu, je nevyhnutnou podmienkou nášho bytia vo svete $v$ najvznešenejšom zmysle slova." (Jackson, cit. in Schein 2003, p. 201). Jackson je v krajinárskej škole autoritou, na ktorú sa odvolávajú neskorší autori.

Táto línia $\mathrm{v}$ americkej regionálnej geografii - landscape tradition - je blízka humanistickogeografickej koncepcii. Zmysel miesta (sense of place) je moderným prekladom latinského genius loci, zdôrazňuje unikátnu kvalitu, atmosféru miesta, jeho atraktivitu, prostredie, stotožnenie sa s komunitou a špecificky aj vnímanie času a jeho rytmov, resp. posun od zmyslu miesta k zmyslu času (Jackson 1994, pp. $157-161)$. V 60. - 80. rokoch 20. storočia sa začína presadzovat' humanistická geografia ako alternatíva voči pozitivistickej geografii - priestorovej vede. Základným konceptom humanistickej geografie je miesto (Tuan 1977, Matlovič a Matlovičová 2007 a Vávra 2010), ktoré má význam. Koncept sense of place je synonymom regionálnej identity a dodnes s ním pracuje množstvo publikácií (Relph 1976, Tuan 1977 a i.). Tuan (1976, p. 272 - 273) zdôrazňuje, že identitu miesta tvorí jeho fyzický charakter, história a spôsob, akým l'udia využívali svoju minulost' na podporu regionálneho vedomia. Humanisticky chápaná regionálna geografia je umením, ktoré dokáže zachytit' podstatu miesta a ,živý popis regiónu je azda najdôležitejším prínosom humanistickej geografie“" (Tuan 1976, p. 273). Popri štúdiu miesta ako subjektívnej skúsenosti sa druhý prístup v humanistickej geografii zameriava na symboly a odkazy, ktoré prinášajú (Smith 2009, p. 245).

\section{SOCIÁLNA KONŠTRUKCIA, SUBJEKTIVIZÁCIA A POLITIKA IDENTITY}

Esencialistické chápanie identity versus sociálny konštruktivizmus (o. i. Daněk 2013, p. 93) je zásadným sporom, ktorý priniesli postmoderné sociálne vedy. „Viera v skutočnú (substantial, v zmysle: esencialistickú pozn. autora) identitu determinovanú narodením alebo vlastnou životnou skúsenost'ou bola významne narušená filozofickým a sociálnym myslením 20. storočia. Zároveň sa zdroje a pro- 
striedky identifikácie vo forme externých aktérov rozšírili nad rámec našich najdivokejších predstáv“ (Dunn 1998, p. 3).

Podl’a feministickej epistemológie „,celé vedenie je sociálne vytvárané“ (Daněk 2013, p. 102). Postmodernizmus tvrdí (Daněk 2013, p. 110), že dôvodom existencie vecí nie je skrytá a konštantná esencia, ale naša zdiel'aná predstava existencie týchto vecí. Sú teda sociálne vytvárané (konštruované) a, pretože spoločnost' sa mení, môžu sa menit’ aj kategórie identifikácie (rasa, rod a pod.). Dunn (1998, p. 2) v súvislosti s postmodernizmom píše o destabilizácii identity.

Prudký rast záujmu o identitu sa viaže na obdobie od 60. rokov 20. storočia. Súvisí aj s konceptom subjektivizácie nadväzujúcim na ohlásenie „smrti autora“: „,... Zrod čitatel'a musí byt' vykúpený smrtou autora“ (Barthes 2001). Význam do textu nevkladá autor, ale vytvára ho čitatel' a interpretácie môžu byt' rôzne. Moranová (2015) tvrdí, že identita je nová idea, ktorá sa objavuje v 60. rokoch. Koncept identity bol do tohto obdobia spätý s totožnost'ou, identitou jednotlivca - personálnou identitou a skupinovou - sociálnou identitou. Vývoj od 60. rokov 20. storočia reflektoval sociálne zmeny toho obdobia (counterculture - protikultúra 60. rokov) a do popredia sa tak dostali otázky menšín, predovšetkým rasových a žien. Venn (2000) zdôrazňuje nástup postštrukturalistickej kritiky projektu modernity v 60. rokoch 20. storočia. Kritika modernity a najmä kritika pozitivistickej vedy (predovšetkým marxistická) boli reakciou na sociálne zmeny 60. rokov 20. storočia.

Ďalší posun zmyslu pojmu identita nastáva v 90. rokoch 20. storočia, resp. na prelome storočí. Menšiny boli pôvodne definované na základe nerovnosti, resp. „,neadekvátneho podielu na moci“. V tomto období však silnie politika identity s rastúcim významom marxistického chápania sociálnych vzt’ahov. Marxisticky orientované sociálne vedy a filozofie (radikálny feminizmus, postkolonializmus a samotné marxistické prístupy) zdôrazňujú odlišnost' (diferenciu); koncepcia identity sa tak mení od totožnosti k odlišnosti. Crenshaw (1989) konceptom intersekcionality prináša pohl'ad na diskrimináciu (utláčanie - oppression) na základe viacerých kritérií (ako ženy a zároveň ako čiernej a pod.), a tak ,identita žien musí byt' bázou pre politickú akciu“" (Lloyd 2005, p. 5). Politika identity má výraznú väzbu na feministickú teóriu. Čast' kritickej feministickej teórie má charakter radikalizácie a konfrontácie: , ,.. naša krajina je imperialistickým belošsko-rasistickým kapitalistickým patriarchátom." (imperialist white-supremacist capitalist patriarchy; Hooks 2003, p. 10).

Postštrukturalizmus prispel k d'alšej redefinícii identity, mnohonásobné významy a spôsoby identifikácie sú dôsledkom vzt’ahov $\mathrm{v}$ textoch a v kultúrach (Murdoch 2006, p. 9). A Murdoch dodáva, že význam nie je vytváraný jednotlivcami, ale sústavami textových, kultúrnych a sociálnych vzt'ahov. Citovaný autor charakterizuje postštrukturalistickú analýzu o. i. dôrazom na systémy a nie na jednotlivcov (Mudroch 2006, pp. 9-10). Vytváranie významov a identít je subjektom bojov a súperenia, ktoré sú politickými a mocenskými. Subjektivita, význam a identita sú „decentro-vané“ a fragmentované, nie sú stabilné, ale sa menia. Postštrukturalistické chápanie identity súvisí so subjektivitou a mocou. „Postštrukturálne teórie pojem identita nahradili pojmom subjektivita, ked’že identita sa vzt’ahuje k celistvosti, súdržnosti a jedinečnosti, a postmoderný subjekt je dekonštruovaný, nie je autentický, pretože je produkt moci“" (Kulašíková 2012, p. 255).

Brubaker a Cooper (2000) rozlišujú medzi silnými koncepciami identity s dôrazom na totožnost' (podobnost', rovnakost' a esencializmus), vnútornú homo- 
genitu a uzavretost' a v súčasnosti presadzovanými „slabými“ chápaniami identity, ktoré sú sociálne konštruované. Zdôrazňujú pritom okrem iného tzv. klišé konštruktivizmu - rutinné spájanie slabých a silných koncepcí́ identity vedie k tomu, že výsledná mnohonásobná, nestabilná (vid' napr. Berger a Luckmann 1999, pp. 100-101), fragmentovaná a nestála identita je nezrozumitel'ná a neskúmatel'ná. „Mäkký“ konštruktivizmus umožňuje množenie domnelých (putative) identít" (Brubaker a Cooper 2000, p. 1). Konštruktivistické poňatie identity podl'a Brubakera a Coopera koncept oslabuje a znemožňuje jeho použite ako analytického nástroja. $\mathrm{V}$ súvislosti s tým autori navrhujú namiesto identity tri analytické konceptuálne nástroje: identifikáciu, seba-uvedomenie a „skupinovost" (groupness, zmysel spolupatričnosti k skupine). Schröder (2009) ponúka iné alternatívne koncepty pre analýzu kolektívnej identifikácie: Gramsciho koncept hegemónie a koncept sociálneho priestoru a habitusu Pierra Bourdieua.

Pôvodný zdroj sociálneho konštruktivizmu (Berger a Luckmann 1999) začína epistemologicky, zameriavajúc sa na sociológiu vedenia, ale jeho dedičstvo spočíva predovšetkým, ako sa odzrkadl'uje aj v názve, v sociálnej konštrukcii skutočnosti. Argumenty spochybňujúce sociálny konštruktivizmus zhrňuje de Lara (2000). Jeden argument je spätý s otázkou: „Kto konštruuje?“ súvisiacou s nejednoznačnost'ou gramatického tvaru konceptu. Ak je sociálna konštrukcia konštrukciou spoločnosti (niekým iným ako je ona sama), skutočnost' je iba mentálnym výtvorom; ak je to spoločnost' (inštitúcie), ktorá konštruuje, konštruovaní sú jednotlivci a ich myslenie, ide teda o konštrukciu seba zo seba, determinizmus inštitúcie (,mysliace inštitúcie“" udel'ujú identitu; Douglas 1986). Politizácia vedie k d’alšiemu zahmlievaniu reality: „... konštrukcionizmus ponúka akúsi alternatívu, ktorá by umožňovala v dobrej viere zjednocovat' rôzne dimenzie politična a politiky bez toho, aby ich redukovala, a to tak, že pracuje s predstavami ako s vecami a s vecami ako s predstavami“" (de Lara 2000, p. 264).

Politika identity, pôvodne zameraná na oslobodenie od nespravodlivostí minulosti, sa sama stáva nástrojom zacieleným na „bielych utlačovatel'ov“ (Mitchell 2019, p. 19): „Politika identity preberá myšlienku viny a určuje dlžníka“ (Mitchell 2019, p. 247); dlžníkom je biely muž či krest’anstvo. Reilly-Cooper (2013) kritizuje spätost' politiky intersekcionality so subjektívnym pocitom útlaku. Autorka zdôrazňuje, že v takom prípade by sme dokonca nemohli ani implementovat' zákony proti sexuálnemu napadnutiu.

\section{REGIÓN A REGIONÁLNA IDENTITA V SÚČASNOSTI}

Geografiu a chápanie geografickej (regionálnej) identity ovplyvňuje vývoj v sociálnych vedách. Sociálne vedy sa zameriavajú na individuálnu a skupinovú identitu. V prípade individuálnej identity ide o personálnu totožnost', založenú na vnímaní seba, svojej odlišnosti, na askriptívnych prvkoch svojej identity (vek, pohlavie, rasa a pod.) a na potrebe niekam patrit' - sem patria aj priestorové formy identifikácie.

Sociálnokonštruktivistické chápanie reality sa postupne, najmä od 80. rokov 20. storočia, stáva dominujúcim prístupom. Creswell (2013, p. 71) uvádza: „Ústrednou v novej regionálnej geografii bolo presvedčenie, že regióny sú sociálne konštrukty“. Analýza geografickej literatúry naozaj naznačuje, že ide o vieru, prijatú premisu, axiómu, o ktorej sa nediskutuje. A iba málo autorov na to upozorňuje (Marek 2020b). 
Pribúdajú štúdie, ktoré sa zameriavajú na teoretické uchopenie prístupu (Thrift 1983, p. 28) zdôrazňujúci kontextuálny charakter sociálnej vedy, skúmajúcej l’udskú aktivitu ako sociálnu udalost', ako ,sériu udalostí situovaných v priestore a čase“); procesuálny a kontingentný charakter sociálneho konštruktu (Pred 1984) a pod. Región je tak pod vplyvom súčasného vývoja $\mathrm{v}$ sociálnych vedách a $\mathrm{v}$ geografii chápaný ako „historicky kontingentná sociálna konštrukcia“ (Tomaney 2009, p. 140), ako historicky kontingentný proces (Pred 1984).

Chápanie regionálnej identity sa mení v zhode so zmenami chápania regiónu, resp. miesta. Miesto je v súčasnosti ponímané konštruktivisticky a postmoderne (place as assemblage - Deleuze a Guattari 2010 a Dovey 2010) a často sa zdôrazňuje vzt'ah miesta a identity s konceptom habitu (Bourdieu 1998, Dovey 2010 a Cresswell 2013). Habitus prekonáva dualitu štruktúry a konania - l’udia sa vnútorne stotožňujú s vonkajšou štruktúrou a súčasne túto štruktúru vytvárajú (Daněk 2013, p. 123). Cresswell (2013, p. 205) v zhode s novou regionálnou geografiou charakterizuje priestorový kontext habitusu: „Jednotlivé priestorové usporiadania miesta, teritóriá, regióny - v rôznych mierkach sú nepretržite vytvárané, reprodukované a transformované v kontextoch existujúcich priestorových usporiadaní“.

Masseyová definuje globálny význam miesta pomocou vzt’ahov spájajúcich miesto s inými miestami (vid' Daněk 2013, p. 137). Vzt'ahy sú rôznorodé, a preto aj miesta musia byt' vnútorne heterogénne. „Ak môžu mat' l'udia viacnásobné identity, potom môžu mat' aj miesta viacnásobné identity“ (Massey 1994, p. 153). Od 90. rokov 20. storočia sa začína viac zdôrazňovat' rôznorodost' (heterogenita), menlivost'. Posuny v chápaní regionálnej (geografickej) identity, resp. identity v geografii, je možné sledovat' aj v geografických slovníkoch, encyklopédiách a ikonických dielach. Chápanie identity je v nich odlišné od súčasných (najmä empirických) štúdií zameraných na regionálnu identitu; tento problém je však rozsiahly a jeho riešenie by si vyžadovalo samostatnú štúdiu.

Heslo „Identities“ v The Sage Handbook of Human Geography (Dowling a McKinnon 2014) prezentuje identity najmä v politickom a postštrukturalistickom zmysle a zdôrazňuje nastávanie (becoming) a asambláž identít, gendered identities a identifikáciu; autorky ,tradičné“ formy identity vôbec nespomínajú.

Terlouw (2018) vychádza pri charakteristike identity z personálnych identít, ktoré nie sú fixné, ale premenlivé (fluid). Z hl'adiska geografickej identity autor predkladá isté napätie medzi regionálnou identitou spätou s priestorovými prvkami (budovy a krajiny) a lokálnou identitou so silnými sociálnymi väzbami, ako aj medzi regionálnou a národnou identitou. Regionálna identita podl’a Terlouwa nie je fakt, ale „sociálny konštrukt, produkovaný a reprodukovaný v diskurze. Diskurzy regionálnej identity sú pluralitné a kontextové. Generované sú prostredníctvom sociálnych praktík a mocenských vzt’ahov v regiónoch a vzt’ahmi medzi regiónmi ..." (Paasi 2013, p. 4). Paasi toto poňatie dáva do kontrastu s regionálnou identitou ako empirickou entitou definovanou jej vlastnost'ami a s identitou ako produktom identifikácie obyvatel'ov regiónu (vid' aj Paasi 1986).

Dve najvýznamnejšie geografické publikácie encyklopedického charakteru heslo identita akcentujú odlišne. International Encyclopedia of Human Geography obsahuje iba heslo identity politics; autor charakterizuje identitu ako súbor sociálne konštruovaných charakteristík, prostredníctvom ktorých organizujú členovia skupiny zmysel príslušnosti (Kobayashi 2009, p. 282). Piate vydanie The Dictionary of Human Geography (Dubow 2009) charakterizuje vývoj konceptu identita v postup- 
nosti: totožnost' racionálneho subjektu (J. Locke); symbolický subjekt (G. H. Mead) s identitami v širších sociálnych vzt'ahoch, ale stále stabilnými; marxistické poňatie identity ako dôsledku sociálnej štruktúry; Lacan a psychoanalýza zdôrazňujúca identifikáciu ako imaginárne hl'adanie a jedinca „rozpadnutého“ do rôznych systémov sociálnych poriadkov (jazyk, sexuálna odlišnost', ...); politika identity; vnímaná (imagined) komunita a postkoloniálna teória, narúšajúca tradičné pohl'ady na komunitu; v súčasných podmienkach migrácií a transnacionalizmu prinášajúca nové pohl'ady: ,out of place a in-between, ambivalencia, hybridita a transgresia.

Encyclopedia of Geography predstavuje identitu ako posun z tradičného chápania personálnej a sociálnej identity k súčasnému chápaniu identity ako „objavujúcej sa“" (emerging) v špecifických historických, sociálnych a politických kontextoch (Ehrkamp 2010, p. 1 527), súčast' mnohonásobných identifikácií; identity sú menlivé a hybridné, produkt sociálnych interakcií. Jedným zo znakov posunov v chápaní konceptu identity v geografii v súčasnosti je používaný plurál identities (Ehrkamp 2010, Dowling a McKinnon 2014 a Terlouw 2018). Politika identity (resp. identít) ovplyvnila chápanie identity aj v geografii (podobne ako v sociálnych vedách). Možno teda skonštatovat', že identita v geografii prestáva byt' ,geografickým konceptom", stáva sa sociálnou, resp. politickou kategóriou.

\section{DISKUSIA}

V úvodnej časti sme spomenuli úlohu aktérov ovplyvňujúcich meniace sa vedomie spoločnosti, ktorého dôsledkom je často až nekritické prijímanie zmenených chápaní základných konceptov, vrátane identity. Typickým príkladom je v súčasnosti nespochybňované sociálnokonštruktivistické chápanie regiónu a jeho identity. Hlavným dôvodom našej kritiky nie je samotné sociálnokonštruktivistické chápanie regiónu a jeho identity, ale nekritické preberanie a používanie tohto chápania ako jediného možného prístupu. Koncepcia regiónu ako sociálneho konštruktu môže íst' $\mathrm{v}$ istých prípadoch „,proti zdravému rozumu“, napr. pri ceste l'udoprázdnou divočinou Grónska.

Berger a Luckmann ako prví konštituovali sociálnokonštruktivistický charakter reality (1999, pôvodne 1966). Svoje tvrdenia však neargumentujú, skôr na viacerých miestach iba konštatujú, napr.: „Od okamžiku narodenia je vývoj l’udského organizmu a rovnako vývoj väčšej časti jeho biologickej podstaty ako takej podrobený neustálemu spoločenskému vplyvu“ (Berger a Luckmann 1999, p. 52). Navyše ich pôvodným zámerom bolo zameranie sa na sociológiu poznania, ale sami sa posunuli k sociálnej konštrukcii reality. Ako o ich štúdii píše Alieva (2016, p. 43): „,... knihy (Berger a Luckmann 1999), názov ktorej svojou výzvou o niečo prekročil ten program, ktorý kniha reálne nastol’uje.“

Argumenty de Laru (2000 - vid' koniec kapitoly Sociálna konštrukcia, subjektivizácia a politika identity) sú zamerané na substantívum „,konštruktivizmus“. Sporne môže vyznievat' aj adjektívum ,sociálny“. Sociálny konštruktivizmus definuje konštrukciu na základe sociálnej interakcie, v skutočnosti však ide často o činnost’ jednotlivca. Sociálny konštruktivizmus predpokladá aktívnu činnost'; slovo sociálny však smeruje k spoločnosti, nie k človeku ako l'udskému aktérovi. Sociálny konštruktivizmus teda zdôrazňuje aktívnu úlohu sociálnych vzt’ahov, sociálneho kontextu. A (tak) vyvstáva otázka, či je možné považovat' za identitu niečoho (veci, osoby a regiónu) to, čo je identitou kontextov, vlastností a vzt'ahov. 
Sociálna konštrukcia (ako nespochybnitel'ný a nedokazovaný fakt stojaci za všetkým, vrátane prírody) je teda ilúziou. Zároveň je však aj (naším) argumentom: zdôrazňujúc úlohu sociálnych aktérov - čo umožňuje analyzovat' dynamické sociálne zmeny (Alieva 2016) - upozorňuje na to, ako je sama presadzovaná. Presadzovaná je po prvé prostredníctvom subjektivizácie identity a regionálnej identity. Dôsledkom je personalizácia, ktorá vlastne ňou nie je. Nehl'adí totiž na človeka ako takého - teda ako na jednotlivca, ale iba na človeka ako „súčast' sociálnej kategórie“. A po druhé je sociálnokonštruktivistický prístup k identite presadzovaný politikou identity. Identitárna politika určuje - prirad’uje a vylučuje čo je (napr. transrodová identifikácia) a čo nie je (napr. konzervatívne hodnoty) súčast'ou identity. Samotná politika identity sa tak mení z potrebnej pozitívnej diskriminácie utláčaných menšín na nástroj moci. Sociálne-konštruovaná identita nie je iba konštruovanou, nie je konštruovanou sociálne a $\mathrm{v}$ geografickom prostredí nie je ani regionálnou. Touto „de-geografizáciou“ ide geografia sama proti sebe a „dáva si akoby vlastný gól".

Mnohé štúdie z oblasti novej regionálnej geografie, zamerané na regionálnu identitu, nie sú orientované na región ako taký, ale na spoločnost', proces, kontext, prípadne situovanost' a historickú kontingentnost'. Práve nedostatok týchto perspektív je vytýkaný tradičným prístupom považujúc ich tak za esencialistické, fixné, idiografické a „,nevedecké“. Preto sa pokúsime stručne vyvrátit’ tieto námietky.

1) Tradičná regionálna identita nie je sociálna. Tradícia kultúrnej krajiny od Sauera cez Jacksona až po Meiniga zdôrazňuje kultúrny a sociálny akcent v krajine. A podobne je to $\mathrm{v}$ prácach $\mathrm{s}$ humanistickogeografickým chápaním miesta a jeho identity. Príkladom môže byt' charakteristika bostonského suburbia Beacon Hill (Tuan 1974, pp. 212-213), výnimočnej a špecifickej štvrte vyšších vrstiev, charakteristickej svojím sebavedomím, superioritou, exkluzivitou a tradíciami.

2) Tradičná regionálna identita nie je $v$ zhode s duchom doby, ale obracia sa nostalgicky k minulosti. Opät' by sme mohli uviest' viaceré opačné príklady, spomenieme aspoň Jacksona. Aj v pokročilom veku stále akceptoval zmenu a nové impulzy. Dáva dôraz nie na konzervovanie starého, ale vo význame miesta zdôrazňuje kontinuitu a rastúci vplyv nových prvkov - kamiónov a dial'nic (Jackson 1994).

3) Nová regionálna geografia a d'alšie postmoderné prístupy vidia región a jeho identitu ako výsledok podmieňujúcich procesov. To však nie je v geografii nové a orientácia na procesy je vlastná aj viacerým predstavitel’om tradičnej regionálnej identity. Meinig (1972) interpretuje americký Západ (resp. skôr „Západy“) ako dynamické regióny. Skúma, ako sa počiatočné jadrá transformovali cez štyri všeobecné fázy rozvoja v štyroch všeobecných kategóriách, ktorými sú počet a priestorové rozmiestnenie populácie, intraregionálne a interregionálne pohyby, politické oblasti a lokálna kultúra.

4) Nové smery približne po roku 1980 zdôrazňujú úlohu kontextu. V tradičnom chápaní regionálnej identity úlohu kontextov, prostredníctvom ktorých vstupujeme do identity, spĺnajú symboly (Jackson 1994): popri spomínanom kamióne a dial'nici sú to napr. pueblo, mobilný dom, mestský park a šachovnicový vzor (ulice amerických miest, pol'nohospodárske farmy). Jackson demaskuje tradičné chápanie binárneho postavenia domova (home) ako symbolu stability, úkrytu a identity i cesty (road) ako symbolu migrácií a invázií. Zdôrazňuje funkciu cesty v zmysle vzájomného prepájania a nemožnost' jej existencie bez destinácie (Jackson 1994, p. 
189). Dáva tak do protikladu význam miesta a „význam slobody“ (sense of freedom) a uzatvára: „Cesty už nielen vedú k miestam; oni sú miestami.“ (Jackson 1994, p. 190).

5) Výhrada, že tradičná regionálna identita je fixná, nemení sa. Meinig (1969) publikoval vynikajúcu interpretatívnu esej Imperial Texas. V prvej časti Implementácia popisuje, ako varieta prostredí vytvorila kultúrnu varietu, dve výrazne odlišné kultúrne oblasti. V druhej časti predkladá Potvrdenie imperiálneho sna a mýtu. Nasledujúca kapitola Expanzia vysvetl'uje populačnú a geografickú expanziu a úlohu železníc v integrácii nových regiónov k USA a priestorovú reorientáciu Texasu z Mexického zálivu na St. Louis a Chicago. Štvrtá kapitola Rozvoj zdôrazňuje úlohu ropy a spracovatel'ských odvetví v modernizácii Texasu, ktorý si však stále zachováva svoju výlučnost'. V časti Diferenciácia charakterizuje proces vzniku deviatich špecifických regiónov a na záver v Charakteristike presúva dôraz z regionálnych častí na vzt'ahy medzi nimi a opät' k celku, k odlišným kultúram štátu, ktoré sa identifikujú s Texasom výrazne viac než s USA.

6) Výhrada, že tradičná regionálna identita je „objektívnou“; subjektívnost’ nových prístupov podčiarkuje o. i. situovanost'. Za situovanú možno považovat' napr. prácu Jacksona (1970). Autor hl'adá esenciálne mesto prostredníctvom cudzinca (host’a, návštevníka - stranger). Ten - trochu autobiograficky - je nezávislým mužom z malého mesta alebo vidieka, nie nevyhnutne turista, prichádzajúci na deň alebo dva, nie vel'mi prosperujúci, hl'adajúci prácu, pracujúci, alebo na krátkej dovolenke ... A preto zastávkami na jeho ceste nie sú luxusné kluby a reštaurácie, ale pohybuje sa po všedných miestach a cestách. Ráz urbánnej krajiny je tak formovaný obyčajným návštevníkom (a obyvatel'om), jeho každodennými potrebami a životom, pohybom i stretnutiami.

Zhrnutie Jacksonovho prístupu je sumárom pohl'adu na krajinu, resp. región a regionálnu identitu. Meinig (1979, pp. 228 - 229) ju predkladá v siedmich bodoch: idea krajiny je zakotvená $v$ živote človeka - žit' $s$ inými; krajina je jednota, celostnost', integrácia komunity a prostredia; porozumiet' krajine je možné iba ako miestu života a práce l'udí; základnou jednotkou krajiny je individuálne obydlie, dom je miestom identity; porozumiet' krajine požaduje dat' primárny dôraz na vernakulárne, na prostredie každodenného života; krajiny sú symbolické, sú odrazom spoločnosti a majú spirituálny význam; a krajiny sa vždy menia. Krajinu je potrebné (vediet') čítat', mat' „oko pre krajinu“. A v zhode s Malým princom (SaintExupéry 1989, p. 44), ktorému hovorí líška: „Správne vidíme len srdcom. Čo je dôležité je očiam neviditel'né.“ Jackson dodáva: „Poznali svoju krajinu srdcom" (Jackson 1994, p. 20).

\section{ZÁVER}

Ciel'om príspevku bolo nielen charakterizovat' vývoj konceptu identita a jeho meniace sa chápanie v sociálnych vedách a dôsledky tohto vývoja na koncept identity v geografii, ale aj diskutovat' o dvoch prístupoch k regionálnej identite: tradičnom a sociálnokonštruktivistickom. Prínos a vlastný vklad príspevku predstavuje predovšetkým jeho explanačný, evaluačný a diskusný charakter. Evaluáciou rozumieme hodnotenie, resp. charakteristiku konceptu identita ako je chápaný v súčasnosti $\mathrm{v}$ sociálnych vedách a $\mathrm{v}$ geografii. Explanáciou rozumieme $\mathrm{v}$ tomto zmysle objasnenie vzt’ahu medzi meniacim sa chápaním konceptu identity $\mathrm{v}$ sociálnych 
vedách a geografii. Diskusiou je kritické zhodnotenie sociálnokonštruktivistického chápania identity v posledných dvoch kapitolách a reakcia na predpokladané výhrady voči tradične chápanej regionálnej identite.

Ked' l'udia interpretujú svet, rozpory sú nevyhnutné. Počúvame tvrdenia, že existujú „správne“ a „nesprávne“ spôsoby, ako pozerat' na krajinu. Príkladom môže byt', ako niektorí „noví kultúrni geografi“" tvrdia, že „,postmoderný“ spôsob interpretácie krajiny je vo svojej podstate lepší (doslova „,nadradený“ - superior) ako zastarané spôsoby nazerania, ktoré odmietajú ako „pozitivistické“, alebo jednoducho „tradičné“ (Lewis 2003, p. 90). Správny postoj vedeckej pokory si vyžaduje akceptovat' jedno i druhé: tradičné a nové prístupy. Tradícia pomáha budovat' súčasnost', preto sa na ňu treba odvolávat' (chýbajúce odvolávky na pôvodné zdroje sú slabinou mnohých dnešných štúdií). A akceptovanie nových prístupov pomáha vidiet' veci v novom svetle, porozumiet' svetu a prispiet' tak k zmiereniu rastúcich kultúrnych rozporov dneška.

\section{LITERATÚRA}

ALIEVA, D. (2016). Kto sa bojí sociálneho konštruktivizmu? Sociální studia, 3, 37-60. ANNETTE, M. (1965). The changing French region. Professional Geographer, 17, 1-5. BARTHES, R. (2001; pôvodne 1968). Smrt' autora. Profil, 8, 8-13.

BAUMANN, Z., MAY, T. (2004). Myslet sociologicky. Praha (SLON).

BERGER, P. I., LUCKMANN, T. (1999). Sociální konstrukce reality. Pojednání o sociologii védéní. Praha (Centrum pro studium demokracie a kultury).

BOURDIEU, P. (1998). Teorie jednání. Praha (Karolinum).

BRICKER, P. (2006). Identity. In Borchert, D. M., ed. Encyclopedia of philosophy, 4. Farmington Hills (Thomson Gale), pp. 567-572

BRUBAKER, R., COOPER, F. (2000). Beyond identity. Theory and Society, 29, 1-47.

CLAVAL, P. (2007). Regional geography: Past and present (a review of ideas, approaches and goals). Geographica Polonica, 80, 25-42.

CRENSHAW, K. (1989). Demarginalizing the intersection of race and sex: A black feminist critique of antidiscrimination doctrine, feminist theory and antiracist politics. University of Chicago Legal Forum, 1, 139-167.

CRESSWELL, T. (2013). Geographical thought. A critical introduction. Chichester (Wiley).

DANĚK, P. (2013). Geografické myšlení: úvod do teoretických př́stupi̊. Brno (Masarykova univerzita).

De LARA, P. (2000). Jeden sociologický přelud: „sociální konstrukce skutečnosti“. Sociologický časopis, 36, 259-274.

DELEUZE, G., GUATTARI, F. (2010). Tisíc plošin. Praha (Herrmann a synové).

DOUGLAS, M. (1986). How institutions think. Syracuse (Syracuse University Press).

DOVEY, K. (2010). Becoming places. Urbanism/architecture/identity/power. Abingdon (Routledge).

DOWLING, R., McKINNON, K. (2014). Identities. In Lee, R., Castree, N., Kitchin, R., Lawson, V., Paasi, A., Philo, Ch., Radcliffe, S., Roberts, S. M., Withers, Ch. W. J., eds. The Sage handbook of human geography. London (Sage), pp. 627-648

DUBOW, J. (2009). Identity. In Gregory, D., Johnston, R., Pratt, G., Watts, M. J., Whatmore, S., eds. The dictionary of human geography. Oxford (Blackwell), pp. 364-366.

DUNN, R. G. (1998). Identity crisis. A social critique of postmodernity. Minneapolis (University of Minnesota Press).

EHRKAMP, P. (2010). Geography and identity. In Warf, B, ed. Encyclopedia of geography 3, pp. 1527-1531. Los Angeles (Sage).

ERIKSON, E. H. (1977). Childhood and society. London (Paladin Grafton Books). 
ESTYN EVANS, E. (1973). The personality of Ireland. Habitat, heritage, and personality. Cambridge (Cambridge University Press).

GOULD, P., WHITE, R. (1986). Mental maps. London (Routledge).

HOOKS, B. (2003). Teaching community. A pedagogy of hope. New York and London (Routledge).

JACKSON, J. B. (1970). Stranger's path. In Zube, E. H., ed. Landscapes. Selected writings of J. B. Jackson. Amherst (University of Massachusetts Press), pp. 92-106.

JACKSON, J. B. (1972). American space: The centennial years 1865-1876. New York (W. W. Norton and Company).

JACKSON, J. B. (1994). A sense of place, a sense of time. New Haven and London (Yale University Press).

JAMES, P. E. (1954). The field of geography. In James, P. E., Jones, C. F., eds. A merican geography: inventory and prospect. Syracuse (The Syracuse University Press), pp. 2-18.

JENKINS, R. (2008). Social identity, 3rd ed. London and New York (Routledge).

JORDAN, T. G. (1978). Perceptual regions in Texas. Geographical Review, 68, 293-307.

KEITH, M., PILE, S., eds. (1993). Place and the politics of identity. London and New York (Routledge).

KOBAYASHI, A. (2009). Identity politics. In Kitchin, R., Thrift, N., eds. International encyclopedia of human geography 5. Amsterdam, Oxford (Elsevier), pp. 282-286.

KULAŠ́́KOVÁ, Z. (2012). Prežijeme krízu identity? In Dudinská, I., Dančišin, V., eds. Kríza v politike - politika v kríze? Prešov (Filozofická fakulta Prešovskej univerzity), pp. 252-260.

LAZOR, P. (2010). Problém identity jednotlivín v priebehu času. Filozofia, 65, 589-594.

LEWIS, P. (2003). The monument and the bungalow. In Wilson, C., Groth, P., eds. Everyday America. Cultural landscape studies after J. B. Jackson. Berkeley, Los Angeles and London (University of California Press), pp. 85-108.

LLOYD, M (2005). Beyond identity politics. Feminism, power and politics. London (Sage).

MAREK, P. (2020a). Region coby dynamický proces a využití konceptu percepčního regionu př́i výzkumu institucionalizace a deinstitucionalizace regionů. Geografický časopis, 72, 193-213.

MAREK, P. (2020b). Region coby sociální konstrukt a kritická diskuze Paasiho konceptualizace regionální identity. Geografie, 125, 47-68.

MASSEY, D. (1994). A global sense of place. In Massey, D., ed. Space, place and gender. Minneapolis (University of Minnesota Press), pp. 146-156.

MATLOVIČ, R., MATLOVIČOVÁ, K. (2007). Koncept miesta vo vývoji geografického myslenia. In Kraft, S., Mičková, K., Rypl, J., Švec, P., Vančura M., eds. Ceské geografie v Evropském prostoru. České Budějovice (Jihočeská univerzita), pp. 181-190.

MATLOVIČOVÁ, K. (2015). Značka územia. Prešov (Prešovská univerzita).

MEINIG, D. W. (1969). Imperial Texas. An interpretative essay in cultural geography. Austin and London (University of Texas Press).

MEINIG, D. W. (1972). American wests: Preface to a geographical interpretation. Annals of the Association of American Geographers, 62, 159-184.

MEINIG, D. W. (1979). Reading landscape. An appreciation of W. G. Hoskins and J. B. Jackson. In Meinig, D. W., ed. The interpretation of ordinary landscapes. New York and Oxford (Oxford University Press), pp. 195-245.

MITCHELL, M. T. (2019). The limits of liberalism. Tradition, individualism, and the crisis of freedom. Notre Dame (University of Notre Dame Press).

MORAN, M. (2015). Identity and capitalism. London (Sage).

MURDOCH, J. (2006). Post-structuralist geography. A guide to relational space. London (Sage).

NORBERG-SCHULZ, C. (1994). Genius loci. K fenomenologii architektury. Praha (Odeon). 
PAASI, A. (1986). The institutionalization of regions: A theoretical framework for understanding the emergence of regions and the constitution of regional identity. Fennia, 164, 105-146.

PAASI, A. (2013). Regional planning and the mobilization of „regional identity“: from bounded spaces to relational complexity. Regional Studies, 47, 1206-1219.

PARSONS, J. J. (1955). The uniqueness of California. A merican Quarterly, 17, 45-55.

PETRUSEK, M., ed. (1996). Velký sociologický slovnik. Praha (Karolinum).

PRED, A. (1984). Place as historically contingent process: structuration and the timegeography of becoming places. Annals of the Association of American Geographers, 74, 279-297.

REILLY-COOPER, R. (2013). Intersectionality and identity politics. [Online]. Dostupné na: https://rebeccarc.com/2013/04/15/intersectionality-and-identity-politics// [cit: 27-72019].

RELPH, E. (1976). Place and placelessness. London (Pion).

ROUBAL, O. (2009). Teritoriální identita v biografických vyprávěních poválečných osídlenců pohraniči severních Cech. Dizertačná práca, Fakulta sociálních věd Univerzity Karlovy, Praha.

SAINT-EXUPËRY, A. (1989). Malý princ. Praha (Albatros).

SAUER, C. O. (1925). The morphology of landscape. In Leighly, J., ed. Land and life: A selection from the writings of Carl Ortwin Sauer. Berkeley and Los Angeles (University of California Press), pp. 315-350.

SCHEIN, R. S. (2003). Normative dimensions of landscape. In Wilson, C., Groth, P., eds. Everyday America. Cultural landscape studies after J. B. Jackson. Berkeley, Los Angeles and London (University of California Press), pp. 199-218.

SCHRÖDER, I. W. (2009). Against identity: exploring alternative approaches to the study of the politics of local culture. Lietuvos etnologija, 9, 77-92.

SMITH, J. M. (2009). Humanism/humanistic geography. In Kitchin, R., Thrift, N., eds. International encyclopedia of human geography 5. Amstredam (Elsevier), pp. 239-250.

TERLOUW, K. (2018). Regional identities: quested and questioned. In Paasi, A., Harrison, J., Jones, M., eds. Geographies of regions and territories. Cheltentham (Edward Elgar), pp. 256-267.

THRIFT, N. (1983). On the determination of social action in space and time. Environment and Planning D: Society and Space, 1, 23-57.

TOMANEY, J. (2009). Region. In Kitchin, R., Thrift, N., eds. International encyclopedia of human geography 9. Amsterdam (Elsevier), pp. 136-150.

TUAN, Y. F. (1974). Topophilia. A study of environmental perception, attitudes, and values. New York (Columbia University Press).

TUAN, Y. F. (1976). Humanistic geography. A nnals of the Association of American Geographers, 66, 266-276.

TUAN, Y. F. (1977). Space and place. The perspective of experience. Minneapolis and London (University of Minnesota Press).

VÁVRA, J. (2010). Jedinec a místo, jedinec v místě, jedinec prostřednictvím místa. Geografie, 115, 461-478.

VENN, C. (2000). Occidentalism. Modernity and subjectivity. London (Sage).

WHITTLESEY, D. (1929). Sequent occupance. Annals of the Association of American Geographers, 19, 162-165.

ZELINSKY, W. (1973). The cultural geography of the United States. Englewood Cliffs (Prentice Hall).

ZELINSKY, W. (1980). North America's vernacular regions. Annals of the Association of American Geographers, 70, 1-16. 
Karol Kas a la

\section{ESSENTIALIST (TRADITIONAL) VERSUS CONSTRUCTIVIST APPROACH TO REGIONAL IDENTITY}

Identity is one of the most used concepts in recent social studies. Social sciences have a crucial role in the development of many disciplines including human and regional geography. Shifts in the understanding of the main concepts (including regions and their identity) originate from the social sciences and as a consequence are reflected in geography. Thus, from the 1980's an understanding of the concept of regional identity has been influenced by social constructivism, politics of identity and poststructuralist subjectivism.

The main goals of this article are: to introduce the "traditional" concept of identity as it was understood in the past as well as (less frequently) today; to provide a brief overview of the changes of the understanding of the concept of identity in the social sciences; and to assess and discuss the consequences of the development of the concept of identity on the changes of the geographical understanding of identity.

An important change in the understanding of the identity concept happened in the second half of the 20th century. The essentialist conception of identity was replaced by the social constructivist one (belief in reality as well as belief in knowledge being socially constructed). The counterculture of the 1960's and the following identity politics as well as post-structural subjectivity have given identity new meanings.

Geography's definition of identity is influenced by the social sciences and above all by important social scientists. Essentialist conceptions of regional identity (in a strict sense as well as in the landscape tradition, sense of place, etc.) is displaced by social constructivist understanding used uncritically. Instead of identity, geographers emphasized identities, understood as contingent, fluid, emergent, hybrid and subjective. The article discusses and criticizes new approaches to identity in the social sciences and geography in the sense of their exceptionalism and specific deficiencies. It tried to refute some objections against traditionally understood regional identity. 